\title{
Music as Spiritual Metaphor in the Cinema of Ingmar Bergman
}

\author{
By Michael Bird
}

Spring 1996 Issue of KINEMA

\section{SECRET ARITHMETIC OF THE SOUL: MUSIC AS SPIRITUAL METAPHOR IN THE CINEMA OF INGMAR BERGMAN}

Prelude: General Reflections on Music and the Sacred:

It frequently happens that in listening to a piece of music we at first do not hear the deep, fundamental tone, the sure stride of the melody, on which everything else is built... It is only after we have accustomed our ear that we find law and order, and as with one magical stroke, a single unified world emerges from the confused welter of sounds. And when this happens, we suddenly realize with delight and amazement that the fundamental tone was also resounding before, that all along the melody had been giving order and unity...

- Rudolf Bultmann ${ }^{(1)}$

I said to myself, it is as if the eternal harmony were conversing within itself, as it may have done in the bosom of God just before the Creation of the world. So likewise did it move in my inmost soul.

- Goethe ${ }^{(2)}$

One Sunday in December, I was listening to Bach's Christmas Oratorio in Hedvig Eleonora Church... The chorale moved confidentially through the darkening church: Bach's piety heals the torment of our faithlessness...

- Ingmar Bergman ${ }^{(3)}$

Ingmar Bergman has frequently indicated the immense significance of musical experience for his own personal and artistic development, just as he has also suggested that human existence at large has need for music. His words suggest that of all arts, music may be the most spiritually meaningful of all. Such is the implication of a story according to which Bergman remarked that while painting is pleasing but not necessary, "music is absolutely necessary." (4)

What is this "necessary" property of music that merits special consideration? Why is it that while all arts may serve the gods, it is the particular art of the muses which is closest to divinity?

The capacity of music to disclose the inner workings of the universe has a strong place in early Christian thought, inspired by its much earlier role in Greek philosophy. Indeed, Pythagorean philosophy made much of the definition of music in terms of its arithmetic proportions. The notion of the world as an ordered realm gained expression in imagery which construed the universe as a structure of mathematical ratios, or, analogously, harmonious musical intervals. At the same time, musical instruments could themselves serve as models, one familiar comparison being that in which the world was seen to resemble Apollo's lute.

The Greek understanding of the musical model of the world was subsumed under the theology of the early Christian church, in which the universe could be understood as a harmony patterned on music. Even the comparison with the musical instrument was sustained and developed as the theological tradition drew upon Greek sources. For Gregory of Nyssa, the musical instrument serves as an image for the human soul, "present everywhere in the body, just as an artist is present in his musical instrument," and he argues that the soul informs different organs of the body as a musician elicits different tones from different strings. Gregory understands the soul as the invisible harmony in the contrasting elements of this world. ${ }^{(5)}$

In Jewish and Christian accounts of human destiny, history begins with a primordial act of creation by which God brings order out of chaos. To the biblical account there corresponds a musical analogy in the idea that harmony brings order from randomness. Such is the theme of the poetic evocation of the creation story 
within the context of a tribute to the patron saint of music. In his A Song for St. Cecilia's Day, 1687, John Dryden writes:

From Harmony, from heav'nly Harmony,

This universal Frame began:

From Harmony to Harmony

Through all the compass of the Notes it ran,

The Diapason closing full in Man. ${ }^{(6)}$

Frequently it is suggested that music is an intrinsic element of the human outlook, and that we are engaged in the musical process by the very encounter with the world and its underlying source of meaning. Musical and mathematical experience may be seen as subliminal actions within our ongoing quest for meaningful life, in many cases hidden from view of conscious deliberation. Leibniz uses mathematical imagery in his observation that "music is the secret exercise of arithmetic of a soul which does not know it is counting."(7) Of course, for Leibniz, the soul is acting in response to the divine initiative itself, since harmony is extrinsic to the definition of God: "If God had not rational creatures in the world, God would still have the same harmony, but alone and devoid of echo." ${ }^{(8)}$

Musical experience is characterized by both the active and passive sides of knowing. Music is not only performed; it is heard. In this respect, musical experience parallels the quest-theme generally, in which discovery is not merely the finding of that which is looked for, but the receiving of that to which one is open in situations beyond that which can be intellectually anticipated. Victor Zuckerkandl puts it well in his observation that "we call 'musical' not only the composer or interpreter but also the sensitive listener."(9) To be musical, then, means not merely to express, but to hear. It will be argued that in many of Bergman's films, the starting-point of understanding and the discovery of meaningful relatedness to others occurs at the point of musical hearing.

The merging of music with the experience of love has a long tradition in the spiritual traditions of many cultures. In the ancient Hindu scriptures, the sound $O M$ is described as that primordial voice which is the very song of the universe itself. In the Chandogya Upanishad we read:

Even as all leaves come from a stem,

all words come from the sound OM.

$\mathrm{OM}$ is the whole universe...(10)

In Hinduism, one of the four paths to fulfillment is that of bhatki yoga, the Way of Love. In contrast to other yogas which resort to mind, work or psychological exercise with their related activities of rational argument, labour at one's calling or physical discipline, bhakti expresses its theme of love through inculcation of emotional experience, heightened by the performance of music -- bells, percussion, stringed instruments and singing.

The Western traditions, too, have come to understand the importance of the connection between love and musical expression or understanding. Origen argued the view that only through charity may we reach true music, entering into union with God, which Origen describes as "the Symphony that is." (11)

The relationship of music and love is grounded also in etymological analysis. Leo Spitzer has drawn attention to the root of such word-stems as cor (heart) and chord (string), reflected variously in such words as chord, accord, concord. In musical structures, many strings or voices unite, bringing individual notes or tones together to create a harmony. ${ }^{(12)}$ The group of related terms can be quickly expanded to include misericordia (mercy), discord (brokenness) chorus or choir (community of musicians) and chorale (sung musical work, the subject being usually religious and in some manner concerned with the divine-human relationship).

The notion of musicality is closely bound up with the question of spirituality, in that both offer up the question of whether these are to be seen as special gifts of particular individuals or whether they are intrinsic properties of humankind -- homo musicalis or homo religiosis. In the case of the latter, we might consider the view of Mircea Eliade that humanity is by definition religious, or Paul Tillich's argument that humankind is always religious, in both its articulations of faith or doubt, since both are poles of the experience of ultimate concern (Tillich's definition of the religious dimension). In the case of the former, we could take as an 
ancient source the view posed by Plato in the Phaedo, that musicality is not the distinctive quality of certain individuals but rather an essential attribute of the human species itself. ${ }^{(13)}$ For a more recent source -- both literary and cinematic -- we have in Roland Joffe's film The Mission (screenplay by Robert Bolt) the conflict between the Jesuit missionaries and the imperialist conquistadors over the definition of the biological status of the Guarnari inhabitants of the paradise-like lands above the falls. For the conquistadors the issue is one of taking as slaves natives who are no more than jungle animals; for the Jesuits, it is the capacity of a Guarnari child to sing beautiful music that proves the existence of the soul and the fact that all humans are made in the image of God.

That musicality is evidence of spiritual being and the means by which we discover our relationship to the cosmos was long ago given eloquent testimony by Boethius:

...the soul of the universe is united by

musical concord. ...For when, by means

of what in ourselves is well and fitly

ordered, we apprehend what in sounds

is well and fitly combined. ...we

recognize that we ourselves are

united by this likeness... ${ }^{(14)}$

\section{Music in Bergman's Life}

If there is a thoroughly consistent theme in Bergman's comments regarding music -- a cantus firmus, we might like to say -- it is his continuous reference to music as a means of communication, as a consolation, and as a source of meaning in his ongoing self-examination as artist and spiritual being.

The question of communication -- its possibilities and its limits -- has generally been formulated by Bergman as a problem of language, speech, words. In some contexts, he has suggested music as an alternative mode of encounter. It is interesting that in his attempts to define cinematic art in relationship to other art forms, he finds the closest connections to be not with drama or the novel or with painting, but rather with music. In an interview in The Saturday Review, he intimates at the potential for greater profundity of expression as the reason for the comparison. "I find it easier to compare film... to music. In pure film and pure music there is a feeling that goes directly to some deeper level."(15) The notion of "deeper communication" is implied in that definition of "musical" sensitivity which emphasizes equally the roles of performing and hearing, acting and responding. The role of film as agent of such communication is in keeping with Bergman's remark, "I often experience a play or film musically" and his contention regarding the relatedness of film to music: "I would say that there is no art form that has so much in common with music. Both affect our emotions directly, not via the intellect... (16) Bergman was to defend his conception of film's emotional, rather than rational, nature, by reference to a contemporary composer whose work had inspired him in the conceptualizing of Winter Light: "I never ask people to understand what I have made. Stravinski once said, 'I have never understood a piece of music in my life. I always only feel.' ...I have exactly the same feeling when I see a play. It is as if I were hearing a string quartet by Bartók. I never try to understand..."(17)

Although the focus of the present discussion will be specifically on the music of Bach, Mozart and Chopin, with attention given to selected cinematic works in which music is both subject and form of the films themselves, it is important to recognize that music has always been uppermost in Bergman's conceptualization. A few examples of Bergman's consideration of the importance of musical works as inspiration for individual films will suffice to indicate this ongoing reflection; he has specifically indicated the following music-film connections, the former often inspiring the latter: Stravinski's Symphony of Psalms (Winter Light), Carl Orff's Carmina Burana (The Seventh Seal), Beethoven's Ninth Symphony (To Joy), Bartók's Concerto for Orchestra (The Silence),

In contrast to words, which Bergman repeatedly calls obstructions to real communication, music is recognized as having the capacity for such meeting of selves at a fuller, emotional level. Bergman once said to Stuart Kaminsky that words are always difficult, but that "the musician writes notes on a score, which are the most perfect signs that exist between creator and performer."(18) Bergman's parleying of the linguistic and musical modes echoes the claim of Victor Zuckerkandl, "words divide, tones unite."(19) It is significant that Boethius, as dedicated as he was to the cultivation of elegant language and clear rhetoric, found it necessary 
to summon up the "grace of music" in order for Philosophy to be able to make her case when it came to persuading the lonely soul of the possibility of higher forms of spiritual fulfillment.

The question of music as consolation arises in those frequent comments Bergman has made with regard to tragedies in his life and amongst friends, for which music has offered solace. In The Magic Lantern, Bergman narrates a particularly moving story in which he considered deeply the relationship between pain in Bach's life and that in his own (much as Algot Frovik, in Winter Light, meditates upon the connections between Jesus's agony and his own). In his own autobiographical account, Bergman recalls a conversation he had once had with actor Erland Josephson, a conversation about the sad occasion when Johann Sebastian Bach had returned from a journey to find that his wife and two of their children had died during his absence. To Bach's written diary entry, "Dear Lord, may my joy not leave me," Bergman was to utter his parallel cry, "All through my life my conscious life, I had lived with what Bach calls his joy. It had carried me through crises and misery and functioned as faithfully in my heart. ...Bach called this state his joy, a joy in God. Dear Lord, may my joy not leave me."(20)

The understanding of music as a source of meaning in his self-reflection is articulated in remarks made to Lise-Lorne Marker and Frederick H. Marker, as they interviewed the director in connection with his theatrical productions. In response to the question of the importance of music, Bergman remarked, "Music has all my life been just as vital as food and drink. ...Music is a great source of strength." ${ }^{(21)}$ It may be this conviction regarding the life-giving nature of music that prompted press reports indicating the possibility that Bergman was prepared to turn his back on filmmaking for an entire year in order to devote his energies to a study of the life and work of J.S. Bach. Describing this possibility as a dream against the ordinariness of work-a-day life, Bergman was quoted as saying, "One must try to realize one's dream and break away from the drudgery of everyday work." (22)

\section{Bach and Bergman}

The significance of the work of Johann Sebastian Bach in the cinema of Ingmar Bergman can be fully appreciated only if one considers that Bach's music is not merely in the films, but is of the films.

Of all composers whose music has been incorporated within Bergman's films, it is Bach who figures most prominently in the ongoing work. At a cursory glance, one encounters Bach compositions used significantly in works as diverse as The Silence (The Goldberg Variations), Cries and Whispers (a Cello Sonata), Through a Glass Darkly (the D-minor Cello Suite), Wild Strawberries (the E-flat minor Fugue), Autumn Sonata (where the cellist Leonardo played "all Bach's solo suites") and to a lesser degree in Hour of the Wolf, The Passion of Anna, Persona and other films.

Thematically, musical works set within these films serve frequently to underline the spiritual condition of individuals or circumstances. In Through a Glass Darkly, the poignant melancholy of the passage from the Bach D-minor Cello Suite serves to accentuate the tragic discovery by Karin of her illness when reading its description in David's diary. Bach Cello Suites are also accompaniments to brief moments of reconciliation and relatedness in Cries and Whispers and Autumn Sonata.. Contrariwise, in Wild Strawberries, the profound sadness of the strains of the E-flat minor Fugue played by Sarah on the piano while Isak Borg looks on from a distance (in a dream-sequence) emphasizes the loneliness of Isak in his inability to have entered into meaningful and loving human relationships. In Shame, Bach's Fourth Brandenburg Concerto is the subject of Jan Rosenberg's yearning dream.

One of the most fully-developed manifestations of Bach compositions within the thematic structure of a film is to be found in The Silence. Here, the soft playing of Bach's Goldberg Variations on the radio in Ester's darkened room has the potential to console the ailing older sister in a manner similar to an earlier historical situation. In its original context, this music had a healing role, for it had brought consolation to the pain-ridden and insomniac Count Keyserling, at whose instigation Bach composed the work for Johann Goldberg. In The Silence, where communication has been broken on all fronts, Bach's music becomes nearly the only personal bridge between Ester and the old waiter. Although they cannot speak the same language, they are able to establish intimacy and commonality of spirit by their shared hearing of this music and their simultaneous utterance of the composer's name. Their intonation of the name "Johann Sebastian Bach," with its notable three-fold repetition of the word "Bach," ${ }^{(23)}$ possesses an almost liturgical quality, in which the participation in the recitation of established words enables the meeting of souls heretofore isolated from 
one another.

But while Bergman's use of music within films may function capably to heighten the expression of conditions of the soul, it is another utilization of Bach's music upon which our attention is most importantly focused. Not only is the music of Bach to be found within these films, like other sounds effects or cinematic devices; more significantly, the music of Bach can be said to be of the cinematic philosophy of Bergman. To explore this integration of music/film as structure, we need to consider the musical form known as the fugue, and related devices with which Bach is associated, not as its inventor, but surely as one of its indisputable perfectionists.

The fugue (literally, "flight") is a type of composition for a set number of parts, with two or more "voices" (instrumental or sung) juxtaposed around a central theme. This central theme -- the "subject," or ground voice (cantus firmus) provides the reference-point, against which other voices serve as interpretation, repetition, parallel statement, contrast, inversion or other form of variation, the whole leading to a harmonic resolution. The hearing experience with regard to fugal compositions is a dynamic listening act, requiring the perception of the process in which fragments are brought together to form the whole. If we use the term "subject" to describe the central voice, we might consider any alternative voice as "answer." In the process by which the parts lead toward a whole greater than its fragments, Subject and answer lead not to another answer, but to Answer.

A related term, but given different formation through the emotional and harmonic complexities of music of the Romantic period, is that of the sonata-form, from the Italian word for "sounded" (suonare, to sound). The variation here is a sequential one (from movement to movement), a temporal counterpart to the spatial variation of the fugue in which varied melodic lines are heard simultaneously. A familiar sonata-form in three movements consists of an Exposition, followed by a Development, culminating in a Recapitulation, this final movement always being more than a repetition, incorporating the sameness of the Exposition with the newness of the Development.

The fugue-like character of Bergman's art has been argued on earlier occasion with regard to a particular film. For Robin Wood, music is a constant reference-point in the analysis of Ingmar Bergman's work, and a particularly compelling case is made for the Bachian quality of the film Wild Strawberries.

Indeed, Wood, in his claim that "the film's construction can best be explained in terms of a time-fugue."(24) sees this particular film as an expression of cinematic counterpoint, comparing its several biographical storylines with the voices of a Bach contrapuntal composition. To understand the life of the elderly Isak Borg, it is necessary to follow his journey from home to Lund and from morning to nightfall by discovering also the unfolding stories of his ancient mother, his daughter-in-law and alienated son, and reflect upon the possible life of the as-yet unborn grandchild. These juxtaposed stories are introduced at various stages and development in differing ways through dreams, flashbacks and actual encounters. We arrive, finally, at the end of the day's journey with an enriched insight into Isak's life by virtue of at last perceiving it within the totality of the relationships of those closest to him, a process comparable to that of listening to Bach's Musical Offering or The Well-Tempered Clavier, in which counterpoint leads to harmonic resolution. Even the details of the final scenes of Wild Strawberries can be seen (or, more properly, heard) as manifestations of the contrapuntal structure, as scenes of childhood and present life are integrated with tentative short musical phrases plucked on strings, culminating in a final intonation accompanying the last image of Isak, with a gentle smile of reconciliation and received loved, settling into a peaceful sleep in the home of his son.

The musical analogy is, however, more than that of the integration of the parts within the harmonious whole, or the contrapuntal juxtaposition of voicings and final articulation of the underlying cantus firmus. If we keep in mind the discussion of juxtaposed linear and circular movements and of repetition and differentiation which are examined more systematically as cinematic geometry, we are given a framework for the fuller consideration of Bach's genius as it is subsumed into Bergman's genius in the structuring of his cinematic work.

The general musical framework with which Bergman's cinematic art reveals the closest affinity is that of counterpoint, defined in one instance as "the ability, unique to music, to say two things at once comprehensibly." (25) For our purposes, we shall have occasion to either contest the "unique to music" clause, or, if we 
accept it, shall do so to the extent that film may be seen in Bergman's assessment to constitute a special form of music. The art of counterpoint as juxtaposition of melodic lines within a unified harmonic structure has roots in Medieval music, but its flowering was to take place after the end of the 16th century, its status greatly enhanced by Johann Joseph Fux's Gradus ad Parnassum, the 1725 theoretical study whose influence was to extend far and wide over the coming century.

In contrapuntal composition, the voices which "surround" the cantus firmus may take several forms. A popular feature in counterpoint is the principle of imitation. Imitation, however, leads to diversity simply as a consequence of its appearance in new contexts (its relationship to the pre-existing voice already makes it more than repetition, since two melodic lines are now a part of the hearing experience). When a line is repeated, its new contextual setting presents the listener with the paradox of seeming similarity and underlying dissimilarity. This dynamic of the apparent and the actual imbues a composition with the sense of having moved forward in time, space and meaning.

Let us consider the notion of musical counterpoint in the cinema of Ingmar Bergman, first by way of a general description, then by a specific reflection upon a particular film.

It is an interesting feature of his cinematic art that Bergman endings tend to look like Bergman beginnings. Events of The Seventh Seal begin by the sea and end at the sea. In Wild Strawberries, the opening scene of Isak Borg reclining upon his pillow is matched ("countered") by the closing scene of him once again reclining upon a pillow. Winter Light begins and ends with a church service. The Magician opens and closes with scenes in carriage. A virtually identical juxtaposition occurs in The Silence, with the train compartment substituted for the carriage. Two letters written by a daughter to her mother establish the parenthetical opening and closing of Autumn Sonata. Even in Fanny and Alexander, Bergman's final feature film, the domestic ritual of life around the banquet table is a double image establishing the beginning and ending of a rich narrative. It might well be argued that these juxtapositions are intentional devices which challenge the viewer to search beneath the similarities of surface appearance for the emergence of profound differentiation in the depths of reality. In each of these di-polar structures, we are invited to explore the double-sided nature of images and cinematic devices which lead from despair to hope, blindness to vision, and, most importantly, from the loneliness of estrangement to the fulfillment of love.

If we take a single film as case-study, we are given opportunity to examine this contrapuntal technique more fully. The events of Winter Light are bracketed by two church services in which Pastor Tomas recites words from the ancient divine liturgy. In this repetition we encounter the possibility through the circular and repeating imagery of this film that nothing has happened to instill hope for a future any different in shape from the past. To all appearances, Tomas remains cold and unfeeling, trapped within a desperate life and set of actions which had never been of his own choosing in the first place. We have begun in a church on Christmas noon and returned to a church on Christmas mid-afternoon, and the "congregation" is even smaller at the second service than the first (in fact, it is constituted by a single individual, the seemingly unreligious Märta whom Blom the organist so affectionately refers to as "the pagan"). Repetition. Cycle of hopeless return. Fatalism. Entrapment. Or so it seems if we perceive only the surface. A far different experience is afforded, however, by the more careful observation of the depths beneath the surface. In this more deeply sensitized reflection, in this "hearing" (a requisite in the defining of "musicality"), the viewer/listener is afforded the possibility of being moved by a deeper reservoir of images. At this more intense level of observation, we may become aware of an accumulation of details which point toward difference-within-sameness. In the opening scene, the church is gloomily lit; in the second scene, a warm (albeit electrical) light fills the interior; the crucifix and its imagery of death in the first setting is replaced by the life-giving image of the Virgin and Child in the second; the weak-voiced Tomas gives way to the more robustly-speaking Tomas of the later service; in the second context, Tomas no longer coughs nor does he wear the glasses which had obscured his face earlier; the indifferent congregation of the first service gives way to the solitary figure of Marta who now kneels and prays intensely in her dark corner of the church; as in the opening scene, Tomas once again recites the text of the liturgy, but with a significant change: rather than speaking the words of closing, he now recites the words of the opening of the service; in an interesting sleight of hand, Bergman has opened with a closing and closed with an opening, using one and the same liturgical text throughout. The appearance of repetition is shattered by the reality of radical change. The cumulative effect of detail is developed in a systematic manner which undermines the possibility of mere repetition. The surface is shattered to disclose 
a deeper reality and a latent groundwork for profound differentiation beyond apparent sameness.

Bach, too, presents the listener with such challenges. When he wrote his astonishing six-part fugue on what has since been called "the Royal Theme" for King Friedrich, he inscribed on the manuscript the acrostic word RICERCAR (Regis Iusiu Cantio Et Reliqua Canonica Arte Restetuta -- "At the King's Command, the Song and the Remainder Resolved with Canonic Art"). ${ }^{(26)}$ The Italian word ricercar (plural ricercari) is an Italian word meaning "to seek." The term was already an old one, and had preceded the term "fugue" in describing that musical form, hinting at the challenged posed for the listener to seek out hidden musical detail within the musical whole. In its reference to the notion of seeking, ricercar is related to the words recherche and research.

Although the only known explicit usage by Bach of this term was on the occasion of his composition of the Musical Offering (of which the six-part fugue was a part), he composed other works in the manner of a ricercar, a notable example including (besides the Musical Offering) his "St. Anne" Fugue or the E-major Fugue in the Second Part of The Well-Tempered Clavier, in which various voices serve as variations on the common subject.

Bach's use of the word is breath-takingly broad in its intention. A typical ricercar (however many sections it included) was but one composition, consisting of connected movements. The Musical Offering, however, presented itself as a series of thirteen clearly separated compositions. To Bach, the coherence among these thirteen sections was seen as no less important than the reality of their physical separation. Thus Bach could refer to the entire work as a ricercar -- "indicating that it lived in his mind as if it were a single composition of complete continuity, a perfectly unified whole." ${ }^{(27)}$

Corresponding to the contrapuntal structure of Bergman's art is an interesting work composed by Bach for organ, known as the Little Harmonic Labyrinth. The image of the labyrinth is itself significant, since the labyrinth is a maze requiring both entry and departure, journey and return. The listener, like Theseus and other labyrinth-explorers, is subjected to many deceptions and is offered paths which may seem to lead one direction when actually proceeding in another. Bach plays such tricks in this composition by having it begin in one key $(\mathrm{C})$, then modulating to another key $(\mathrm{G})$ and seeming to conclude the work while it is still in the G-section, rather than bringing the listener back to the correct resolution of the C-structure with which the music had actually begun. In musical terms, a resolution of the G-key leaves us stranded (without us suspecting it) in the Subdominant of C, still a step removed from proper resolution. In a musical sense, we believe that we are back at the beginning. We think that what we hear at start and finish is the same. What we are missing in our acoustical observation is the actual status of the underlying notes of $\mathrm{B}$ and $\mathrm{D}$ in the $\mathrm{G}$ chord, two notes which hover on either side of C, waiting to "land" in the home key which is at their centre. Like the viewer of the film Winter Light, we are challenged to a more profound form of recherche or ricercar which is capable of distinguishing apparent sameness from fundamental change.

The musical form which perhaps most effectively suggests Bergman's filmic counterpart is that which Douglas Hofstadter has termed the "endlessly rising canon." He refers to a canon within the Musical Offering which is labelled simply "Canon per Tonos" (it is Canon no. 6, known also as the "Modulating Canon"). This remarkable canon seems to conclude back in its home key, but in fact has mysteriously slipped upward a tone from $\mathrm{C}$ minor to $\mathrm{D}$ minor. The process is repeated with its seeming returns to its beginnings, which are really new beginnings set one key higher than before. As Hofstadter so nicely puts it in the language of the journey into unknown parts, "these successive modulations lead the ear to increasingly remote provinces of tonality, so that after several of them, one would expect to be hopelessly far away from the original starting key. And yet magically, after exactly six such modulations, the original key of C minor has been restored."(28) As the poet Gerard Manley Hopkins can describe the movement of water in a poem such as Inversnaid as finding its home because it is imbued with a "homing-pigeon" quality rooted in the divine scheme itself, so perhaps Bach's "Canon per Tonos" enacts musically an instinct from resolution in the hearing relationship which unites individual and cosmos.

Bach had written in the margin of his "Canon per Tonos," "As the modulation rises, so may the King's Glory" (an illustration of Bach's dedication copy of the canon is shown in David, J.S. Bach's Musical Offering). ${ }^{(29)}$ As the king's glory rises, so does the perplexity of the listener attempting to determine her or his musical location. This spiralling movement issues a double challenge, in that we may think we are home when we 
are not, and we may not realize that we are home when we are. What is required, musically, to properly differentiate between apparent key and actual key is the phenomenon of "recursion," a homing-instinct which can lead us to the ground key upon which variation is based. In art it is the capacity for distinguishing between figure and ground. The thematic home-ground in Bergman's cinematic work appears to be centered in those tonalities of redemptive relatedness of outer to inner self and of self to others which animate the narrative movement of films as panoramic as The Seventh Seal or intimate as Fanny and Alexander.

If Bach's achievements were merely those of geometry and numbers, we would have to acknowledge the presence of mathematical genius. Many are the admirers, however, who see in Bach a still greater gift, namely the facility for writing compositions which evoke elements of the sacred. One is not to required to go to such extremes as Bishop Nathan Soderblom's reverential designation of Bach as "The Fifth Evangelist," (for fuller consideration of this remark and its attribution to Soderblom, see Ruth Tatlow's discussion in her study of Bach and the use of number symbolism) ${ }^{(30)}$ to provide convincing argument for the spiritual significance of Bach's music. The sense of holy mystery to which Bach's ear seemed so unerringly attuned and which gained such compelling expression in his work has impressed writers from the early biographer Johann Nicolaus Forkel (1749-1818) to his 20th-century musical disciple Albert Schweitzer. Hermann Rutters concludes that "we recognize through this music that Bach belongs to another world, to which we cannot find entrance... The Art of the Fugue exceeds everything material, even time and style. It belongs to that mysterious atmosphere where the physical becomes transformed into the metaphysical." ${ }^{(31)}$

In response to his insertion of the emotionally captivating Bach Cello Suite in several of his films, Bergman referred to his "ethical motivation" and of its profound ability to speak to deeply-imbedded spiritual strivings in an age when the search for meaning occurs every more frequently outside the churches. "As far as religion is concerned," said Bergman to his interviewer, ... "we live in a time of reconsideration. Bach speaks directly to the religious feelings homeless today in many people; he gives us the profound consolation and quiet that previous generations gained through ritual. Bach supplies a lucid reflection of otherwordliness, a sense of eternity no church can offer today." ${ }^{32)}$ Perhaps it is the sublimity of Bach's music which speaks to many a searching soul, but sublimity in Bach is rarely far removed from the dynamic of the journey, the neverceasing motion toward new possibilities. In thinking of Bach, one thinks musically of the baroque, and that term, indicating something "oblique and not quite rounded," (33) reflected the surprising variation of design in baroque art which distinguished it from the quiet balance of proportions sought in pre-baroque art. In the music of Bach and cinematic art of Bergman alike is to be encountered the striving of melody and line toward harmony and story.

A question remains before us: can we say that the work of Bach and Bergman is religious, or can we do no more than say that some Bach compositions and some Bergman films are religious? In both cases there is an argument to be overcome if we wish to speak of an ongoing spiritual dimension to the work at large. With regard to Bergman, the director himself has suggested that at a certain point he made the choice to leave religious questions behind. About Bach's work, too, it has been claimed that the "religious" compositions were composed within a limited context and a short time-frame, and that the remaining works should be considered "secular." Against these dichotomies, we can say in the case of Bergman that the protagonists of his latest films are no less intent in their search for love and meaning than those in The Seventh Seal or Winter Light. Bergman's introduction of the phrase "holiness of being" to describe the so-called human-focus of his later films is so imbued with elements of universality and timelessness that however far it may take us away from theistic notions of God, it remains firmly planted within the fertile field of human destiny and spiritual possibility. In the case of Bach, we can take note of his own practice of using and re-using "secular" melodies in religious works and, more importantly, his attitude toward craftsmanship and exhortation "that the performance of any God-pleasing vocation was the service of God." It is in this context that Jaroslav Pelikán is persuaded that there is no aspect of Bach's musical vocation that is without religious significance. The case of Ingmar Bergman invites comparison.

It may well be the case that the best argument is that put by Bergman himself: "I want to be one of the great artists in the cathedral on the great plain. I want to make a dragon's head, an angel, a devil -- or perhaps a saint -- out of stone. It does not matter which... Regardless of whether I believe or not, whether I am Christian or not, I would play my part in the collective building of the cathedral." (34) 


\section{Wolfgang Amadeus Mozart and Bergman: General Reflections}

That the music of Wolfgang Amadeus Mozart has been important for Bergman's work is suggested both personally and cinematically. In personal terms, Bergman's comments on Mozart are reminiscent of his general remarks regarding the relative important of painting and music (the former being pleasurable, the latter being necessary). When asked by an interviewer about a reference to Mozart in an Alfred Hitchcock film, Bergman was quick to distance himself from the disinterested view of a character in the film Vertigo. In response to the comment that in this film Hitchcock has a girl say to a physician, "Doctor, I don't think Mozart helps in the least," Bergman remarked, "Mozart helps me tremendously!"(35) To the degree that much of the Mozart music which appears in Bergman films is essentially romantic in character, perhaps Bergman's affirmation of its importance has to do with its salvific capacity. It may well be the case that Bergman's view of Mozart's music is to be placed in the same understanding as that of Paul Bekker, whose study of this musical tradition had on earlier occasion led him to the claim that "all romantic music is music of redemption." (36)

Cinematically, there has long been in Bergman's reflections upon the medium the repeated claim that film and music are inextricably bound up with one another. In some cases, the argument is taken to the point at which film and music are, in fact, one and the same. The instances in which Bergman has described his films in musical terms are many. He has referred to The Seventh Seal as an "oratorio."(37) On one occasion, after listening to his wife Kabi Laretei playing Bartók's Third Piano Concerto, Bergman expressed his wish, "I'd like to make films the way Bartók makes music." (38) In defense of the dramatic (and controversial) ending of Through a Glass Darkly, he has said to the criticism that it seemed as if he were striving for "a sort of Beethoven effect," Bergman accepted his imputed identity of approach, saying, "Yes, we both do it!"(39) This particular film is described elsewhere in musical terms as a variation on a "coda." (40)

The fusing of cinematic art and the art of music has been claimed by others, as well. In an intriguing comparison of traditional musical instruments with the technical workings of cinema, Jean Mambrino has written about The Seventh Seal: "Never did a film demonstrate better, indeed, the soundness of Kafka's words: 'The strings of the lyre of modern poets are immense reels of celluloid'.'(41) The most systematic comparisons of Bergman films to musical structures are made by Robin Wood. At one point he likens Bergman's differing works to that of two composers: "If Smiles of a Summer Night has its source in Mozart opera, then Wild Strawberries is founded on a Bach fugue." ${ }^{(42)}$ On another occasion, Wood proposes an interesting parallel between Winter Light and a pertinent musical work, comparing it to Sibelius's Fourth Symphony. "Sibelius's Fourth -- a work as austere, compressed and enigmatic as Winter Light -- is as far as I know unique among symphonies in ending, not with a decisive fortissimo or pianissimo, but with an indeterminate mezzoforte." ${ }^{(43)}$

In an early essay, Bergman describes musical notes as "the most perfect signs" and voices his contention that "film itself is music." (44) When, at a later time, he was asked by an interviewer why he seemed to be using music less and less frequently in his films, Bergman responded, "Because I think that film itself is music, and I can't put music in music." (45) It is not surprising, then, that the director could describe his charming early film Smiles of a Summer Night as "a bit of Mozart," (46) or that he could use as his title for a later film a phrase from a music critic who compared a Mozart quartet with "cries and whispers." (47)

\section{The Magic Flute}

It is not so much Mozart in general but rather Mozart's opera The Magic Flute which has inspired personal and cinematic reflection by Bergman throughout much of his artistic life. From brief allusions to central thematic position, The Magic Flute has occupied some place in films as diverse as Smiles of a Summer Night, Through a Glass Darkly, Hour of The Wolf and From the Life of the Marionettes. At the centre of this interest in Mozart is the decision made by Bergman which resulted in his cinematic production The Magic Flute, undoubtedly reflecting Bergman's claim that Mozart's opera had been at the forefront of his thoughts for most of his life. ${ }^{(48)}$

Amidst the many interpretations of both the broader and the more obscure meaning of Mozart's opera, there is some consensus that such analysis must take into account the symbolism of darkness/light and of discord/harmony which is at the centre of the journeys undertaken by Tamino. The purity and unflagging commitment to the ideal of love between Tamino and Pamina carries the protagonists through their trials, 
represented as encounters with demonic forces in a lower world of darkness, death and demons. In a form of musical question and response, Tamino's search for love's fulfillment is expressed in eloquent dark/light symbolism. Tamino's anguished cry, "Oh dark night! When will you vanish? When shall I find light in the darkness? is given the response of the chorus from within its temple setting, "Soon, soon or never more!" When Tamino asks the subsequent question, "Does Pamina still love?," the distant but assuring answer of the chorus is given: "Pamina still lives." Bergman indicates in The Magic Lantern that this is the scene from the opera which had moved him most profoundly, and which inspired a scene in his film Hour of the Wolf. ${ }^{(49)}$

The imagery of light and dark, question and answer, which in his film The Seventh Sealemphasized the terrible void within which both sight and voice could so easily wither into nothingness, seems vastly more assuring in his later film of the opera. The act of making this film and, perhaps, the inspiration of the themes of its central subject upon the director's personal life, seem to have been spiritually significant to Bergman. His later reflections, based upon his own return to his working notes, are moving in their confessional simplicity:

So now the filming of The Magic Flute is finished.

It has been a remarkable period in my life. This

joy, this proximity to the music every day! All the

affection and tenderness I encountered...(50)

It is not clear in the final sentence whether this "affection and tenderness" comes from other persons working on the film or from the music itself, described in terms of its proximity and its joy. The two alternatives need not necessarily be separable, given the ongoing affirmations of music's capacity for communication at deeper levels. The personal dimension of music as a veritable person in one's midst offers an affirming alternative to the demons and even figure of death which have elsewhere been so palpable in their presence. In The Seventh Seal, Antonius Blok confronts Death, who proclaims himself as having been at Antonius's side for a very long time; in Fanny and Alexander, the youthful-stand-in for the director himself is informed ominously by the ghost of the dead bishop that he will continue to be present to haunt the young Alexander. To these foreboding forms of presence with their deathly countenance it is perhaps Bergman's testament of faith that music can become a veritable guardian angel in life's journey through demonic trials. Referring to Bergman's treatment of The Magic Flute as a "luminous film," attention has been drawn to this cinematic work as one in which "the darkness is at last dispelled... and the finale is an extraordinary theatrical celebration of reconciliation and fruitfulness." ${ }^{(51)}$ Now it is no longer death or demons that surround the film-maker, like those ghoulish figures surrounding the Knight of Faith in Albrecht Dürer's Knight, Death and Devil. Instead, we have Bergman's own words about this musical and joyful presence: "The Magic Flute became my companion through life." ${ }^{(52)}$

It is difficult, even when discussing Mozart, not to be brought back once again to the centrality of the music of Johann Sebastian Bach. Mozart, who moved in so many directions within his sadly short life, never lost sight of the beauty of counterpoint, and used fugal structures on many an occasion, even within works which were clearly of another ethos and idiom. Bergman's intense affection for this particular Mozart opera, expressing as it does the great divisions but also potential reconciliations of life through imagery of darkness, light, discord and harmony, utilizes a thematic structure of division and unity which has been explored in the discussion of Bach's fugues.

In his most recent autobiography, Bergman narrates a most interesting story which offers insight into this Mozart-Bach connection. Recalling the months prior to the decision to undertake production of a film of the opera, Bergman describes a visit to his home by Andrea Vogler. In the course of conversation, she went to the bookshelf and took down a copy of the score of The Magic Flute. Observing her particular interest in the music, Bergman seems to have felt that this was an opportune occasion to tell her of his interest in making a film. During the exchange of remarks, Andrea Vogler opened the score to the section where two guards with fiery helmets sing the chorus. She paused to make the observation that it was quite remarkable of Mozart, a Roman Catholic, to choose a chorus inspired by Bach. The following comment is what is particularly interesting in this recollection. Bergman draws our attention (and re-enforces his own) to the fact that Andrea Vogler then opened the score wide, held it up to view, and said, "This must be the keel of the boat. The Magic Flute is difficult to steer. Without a keel, it doesn't work at all. The Bach chorus is the keel." (53) This estimate of Bach places him even higher in the angelic order than Karl Barth's assessment, 
when, in 1956, he wrote: "It may be that when the angels go about their task of praising God, they play only Bach. I am sure, however, that when they are together en famille, they play Mozart -- and that then too our dear Lord listens with special pleasure." (54) Even when Mozart's music is at the centre of Ingmar Bergman's cinematic exploration, as it was in 1975, Bach is at the centre of Mozart's music.

\section{Bergman and the Music of Frédéric Chopin}

As with regard to the work of other composers -- notably Bach and Mozart -- the music of Frédéric Chopin can be seen in both its comparatively peripheral and central settings in the films. As there are brief albeit important allusions to Bach in films such as Through a Glass Darkly and The Silence, and a similar positioning of Mozart's music in Smiles of a Summer Night or From the Life of the Marionettes, so too, Chopin's music is sometimes at the edge rather than the centre. In Smiles of a Summer Night, the disconsolate Henrik's playing of "a few stormy bars" from Chopin's Fantasy-Impromptu provides a musical release from his temporary despair before finding himself again in the comforting embrace of Anne. Much bleaker is the setting In Hour of the Wolf where we hear, with difficulty, Chopin music struggling for coherence through the static of the radio in a short scene depicting the incommunicative protagonists Jan and Eva seated at the kitchen table. In Fanny and Alexander, we are given a musical correspondence to the struggle of Alexander against the duality of life/death by the relentless tolling of dark chords of Chopin's Funeral March played at the church rites for Oscar, taken mortally ill during a play rehearsal.

Like that of Bach and Mozart, Chopin's music is also on at least one important occasion made the focal point and structure of the cinematic work. In Autumn Sonata (1978), the mother-daughter dialogue between Charlotte and Eva is conducted as much through (if not more so) the medium of Chopin's Prelude no. 2 in A minor as through their flawed efforts at communication through words.

From the beginning, we are informed as to the woeful inadequacy of words. It is Eva who most angrily voices her discontent with the fallacy of spoken language, saying to her mother: "I hadn't any words because you had taken charge of all the words at home. ...I distrusted your words... I didn't understand your words... Nothing fitted... ." ${ }^{(55)}$ In a similar manner, she expresses distrust of even her husband Viktor, who has frequently spoken "beautiful words" to her.

During the unfolding of this almost claustrophobically compressed "chamber film," the tremendous gulf between mother and daughter is brought increasingly to our and their attention through verbal confrontations about the past and about their differing approaches toward the deteriorating physical condition of the younger sister Helena, who, ignored by Charlotte, has been brought to live with Eva. But the true enormity of the gulf separating mother and daughter is conveyed not semantically but musically. In one of the most remarkable musical scenes ever set to film, each of the two women performs the Chopin prelude, the radical difference in their technical approaches serving as the watermark of two souls otherwise hidden from us and from one another.

In reflecting upon the role of the music of Chopin in Autumn Sonata, we are doing so against the thematic consideration of life and death and

Bergman's ongoing juxtapositions of paradoxical images which frequently allude to their opposites. In his work at large we encounter such reversals of imagery as mother/daughter, doctor/patient, wellness/illness, and, ultimately, life/death itself. It is in terms of such reversals that we are given the possibility of meditating upon the ending of Winter Light as an encounter with an apparent unbelief and seeming absence as a higher faith and profound presence. With these juxtapositions in mind, we may turn to the musical dimension in Autumn Sonata.

The particular musical choice -- the Prelude in A minor -- is itself of no little significance. Many are the historians and critics whose comments upon this particular composition reflect a notable puzzlement and skepticism as to its place in Chopin's work. It has been called "crude," "jarring," and "ugly." Charlotte, in her technical instructions, says that one must play the work so that it sound "wrong." If certain of Bach's works can challenge our orientation by leading us into harmonies and keys which we mistake for the foundation key, this peculiar prelude by Chopin does not even settle into its home key until the final chord.

The contention has been made elsewhere that the music of Autumn Sonata is utilized by Bergman to indicate the limitations of art itself, arguing that Charlotte, who can speak eloquently on performance and interpre- 
tation of music, whether it be the Chopin Prelude or Beethoven's Hammerklavier Sonata, is completely incapable of expressing a similar understanding of life itself. ${ }^{(56)}$ While this dichotomy is painfully evident, its existence does not alter the constructive role of the music itself. The vehement confrontation of the two women through their outraged accusations and -- later -- imploring confessions -- is made possible only by the realization which has come about from the confrontation which has at first taken place at the keyboard.

The sequential piano performances of the same musical text are reminiscent of another double utterance, namely the scene in Persona where two women -- externally presented as nurse and patient -- each recount a highly confessional story. In Persona, the double telling of the single story blurs the distinction between individuals, a counterforce to Alma's desperate attempts to define her self as not-Elizabeth. The two musical "readings" in Autumn Sonata have a reverse effect, serving not to blur such distinctions but rather to indicate the true nature of the gulf between mother-daughter in spite of an initial and superficial impression of accord.

With regard to the performance of the music, it can be seen that it is Charlotte who recognizes the difference in the two approaches taken. When Eva asks for her mother's assessment of her playing (clearly looking for affirmation), she receives only the words, "I liked you." Following an exchange of remarks regarding the true-but-unspoken opinion, Charlotte gives her technical critique. She argues that in the execution of this Prelude, it must sound as if it is somehow incorrectly written or played. "It must never become ingratiating. It should sound wrong. You have to battle your way through it, and emerge triumphant." (57) Perhaps in Charlotte's description of the challenge of the concert pianist we are also able to hear a deeper voice outlining the most profound test of life itself. What is important at this moment is Charlotte's inability to comprehend the world beyond the artistic one. As she herself reveals of her own childhood, much later in the evening, "I was completely ignorant of everything to do with love: tenderness, contact, intimacy, warmth. Only through music did I have a chance to show my feelings." ${ }^{(58)}$ Her ability to feel and understand is sadly confined to that between one artist and another. When by herself she reflects momentarily on her inner feelings, she has to look for a musical counterpart to define its outline:

It hurts. Hurts. Let me see now. Does it hurt in the same way in the Bartók sonata, second movement?...It should go like this: the upbeat pam-pam and then comes a little snake of pain... ${ }^{(59)}$

The conversation with Eva is in a certain sense a conversation with Chopin, placing Eva in the role of a thirdparty listener. Charlotte is able to "read" the composer through his music. "This Prelude tells of pain, not reverie... Chopin was passionate, proud and manly..." "Chopin isn't sentimental, Eva. He's very emotional but not mawkish. There's a huge gulf between feeling and sentimentality." (60) The immense tragedy, of course, is the inability of Charlotte to "read" the inner anguish and hopes of those around her, especially her own daughter.

Beyond the impasse of her isolation from the feelings of others, and beyond the limitations of words, lies the question of whether there may be located a deeper communication through the music itself. In view of Bergman's ongoing use of images of reversal, leading to the discovery of hope where there seemed to have been only despair, light rather than darkness, love instead of lovelessness, and, ultimately, life over death, the particular utilization of this most puzzling of all Chopin Preludes invites our further enquiry.

The A-minor Prelude was regarded negatively by many contemporaries and later composers. It may well have been this particular composition which motivated Robert Schumann to say of Chopin's preludes that they contained "much that is sick, feverish and repellent."(61)

In tone, the A-minor Prelude possesses a drably dirge-like quality. Its steady intonation of sombre chords in the lower register bears distinct resemblance to a funeral march. The death-imagery can be taken still further when one isolates within the harmonics of this strange composition the very notes comprising the introductory section of the Dies Irae, the ancient melodic setting of the Christian funeral rite. The same dark motif which established the opening atmosphere of the Seventh Seal similarly introduces us to the events of Autumn Sonata.

But the death-imagery of this music, like impressions received in many of the cinematic devices utilized 
by Bergman, does not necessarily exhaust its ultimate meaning. The structure of Chopin's composition makes use of the principle of repetition in its tolling of chords. and it is the very device of repetition which in Bergman's art is frequently employed to lead from initial impression to opposite reality. Whether the repetition has to do with liturgical recitation (Winter Light), landscapes and seascapes (The Seventh Seal), postures of sleeping and awakening (Wild Strawberries) or musical performance (Autumn Sonata), the act of repetition takes the form of a meaning-giving re-creation in which surface yields to depth and apparent sameness to radical otherness. From time immemorial, it has been known that such incantations of words previously uttered can bring about events hinted at behind the meaning of words. Whether in the ancient Egyptian practice of four-fold reiteration of formulas, or of the Christian three-fold utterance of the Kyrie Eleison (Lord Have Mercy) or Holy, Holy, Holy of the divine liturgy, there is recognized a potential in the act for the transformation of reality. "Repetition is imitation, reaching back into a magical past...," ${ }^{(62)}$ permitting a re-participation in an original act of creation. And, of course, the very naming of the experience offers the possibility of gaining power over the reality to which the experience refers (hence the common prohibition in certain religious traditions of uttering the name of God).

In the repetition of the words of the funeral rite, the chanting of the Dies Irae provides not merely an immersion in the thought about death but, more importantly, an ordering of the cosmos of which death is a part but not the totality. The gathering of the faithful to hear and to intone the incantations of the liturgy for the dead enabled just such an ordering and transcending, and was given its tangible ritual form by Thomas of Celano (d. 1256), to whom the familiar Gregorian melodic line of the Dies Irae is commonly attributed. So well-known is this theme that it has appeared in many Mass-settings through the centuries, and has been utilized in diverse contexts. While it was especially attractive to romantic composers (who, in the assessment of Kenneth B. Klaus, "were almost necrophiles" (63) the theme has been used also by Rachmaninoff in his Isle of the Dead and Rhapsody on a Theme by Paganini, in Nicholas Lenau's Faust (the "Mephisto Waltz" and the Totentanz for piano and orchestra), and by Berlioz in his Symphony Fantastique. It has occasionally appeared in films, notably in Milo Forman's Amadeus and Mike Nichols' Who's Afraid of Virginia Woolf? Its hidden position in Chopin's A minor Prelude sets an initial tone and is the underlying structure of what on the piano keyboard acts as an instrumental counterpart to a sung repeating incantation. What is particularly significant is that as the motif is repeated, it gradually gives way to a continuous melodic line which serves to unite the fragments of the whole. The concluding section of the Prelude is especially noteworthy in that the walking chords lead to a final resolution. Against the dirge of the lower register is juxtaposed a long line of melody hovering overhead. In the description of Ernest Lubin, "If this piece seems to express an acute despair, beyond words, then at least the final chords suggest a note of reconciliation and acceptance."(64)

In a structural form analogous to that of atonal music, the late- night verbal encounter between the two women can be seen as a series of utterances which are more like assaults, stabs and blows than the sustained continuities of melodic development. As the verbal exchange unfolds in time, however, something new is experienced: the isolated cries of the daughter become those of the mother, and those of the mother become those not only of the daughter but even of the younger sister, particularly as each cries out for the mothering love of the other. Individual parries are gradually transformed into a common incantation, a liturgical totality of cries and prayers. And, when Charlotte has in subsequent days returned to her departing train, providing a visual image of separation of mother and daughter, we have another of those repetitions in which seeming imitation discloses underlying change: Eva writes a second letter, inviting her mother to come to her, but with a dimension of urgent intimacy radically different from the rote politeness of the initial text. As Tomas's second recitation of the text in Winter Light is now undertaken in a new spirit within a new possibility of uttering and hearing, so this second reaching-out between Eva and Charlotte (containing Eva's imploring cry, "It must not be too late") is pregnant with new possibility of fulfilled communication and love.

Chopin is the necessary musical presence for Eva and Charlotte, opening dimensions of communication where words alone cannot suffice. The sonata's characteristic three-fold structure of statement, development and recapitulation is given cinematic equivalency in Bergman's work. Bergman's film, no less than the musical sonata, travels the journey from the initial utterance to the interpretation of the utterance and, finally, to the repetition which is always more than imitation. It is a profound movement behind and beyond repetition, as imbued with higher meaning as those stiffly repeated walking figures of virgins and martyrs depicted in 
the wall mosaics of the 6th-century church of San Apollinare in Classe near Ravenna, leading the viewer ever forward to the apse and its symbolic reference to the sacred cosmos.

\section{Postlude: From Fragment to Harmony}

As we examine music within Bergman's films, and consider also those instances in which the very structure of narrative events, dialogue and cinematic techniques is frequently analogous to music forms themselves, we are drawn back to Bergman's own sense of urgency when he deems music, of all the arts, to be "necessary." We have considered this necessity in terms of its capacity for richer levels of communication, recalling the director's comments to the interviewer in Saturday Review, that "in pure film and music there is a feeling that goes directly to the same deeper level." In the context of the present discussion, and with respect to a broad range of films, we have repeatedly noted Bergman's particular criterion for fulfilled communication, that is, the degree to which the love rooted deep within the soul is enabled to be heard, felt, sensed or in some way received in the soul of another. In the music of all ages, and particularly in his intense incorporation of music by Bach, Mozart and Chopin as the central structure of the films considered here, we are given musical expressions of great emotional intensity, and, especially, of potential unity among hearers. Bergman's utilization of music as the structure which bridges the broken condition of spiritual relationships serves to integrate music and love, chord and cor. The concern for the harmonization of self to other and outer self to inner self, amidst the discord of present experience, may be seen to be

Bergman's underlying concern, his cantus firmus. His placement of hope in this "necessary" form, offering the possibility of communication, consolation, healing and love where speech often fails, is Bergman's cinematic explication of the claim, "words fail, tones unite." Perhaps it is music's special attune-ment to the deeper rhythms of the cosmos which permits it to serve as a spiritual leaven when incorporated within another artform, notably cinema, or which defines the spiritual potential of cinema because of what Bergman regards to be the inherent affinity of film to music. When the structure of the film becomes that of the fugue and the sonata, it may well be the case that cinema, too, becomes like unto Leibniz's view of music as the secret exercise of arithmetic of a soul which does not know it is counting.

In an interview with Birgitte Steene, Bergman has made a claim of enormous spiritual significance: "Any drama is worthless which does not deal with man's relationship to metaphysical questions." ${ }^{(65)}$ Like the musical fugues and sonatas, Bergman's films challenge us through structures which convey initial impressions of sameness and defeat, beneath which are to be seen and heard profound stirrings of change and hope. Could not Bergman's cinematic work, emerging from the sanctuary of the theatre, dreams and childhood, returning to that very place in the closing scenes of the final feature film (Fanny and Alexander) be discovered to comprise a grand ricercar, with juxtaposed variations on a common ground, ever offering the challenge to seek out the underlying harmonic tonalities beneath the surface of complex and competing sounds?

Discerning the relationship of the parts to the whole, of harmonics to melody, of solo voices to chorus, of partial impression to underlying revelation -- this is the challenge posed at many levels of experience through Bergman's work. It is after coming through a day's long and difficult journey that Isak Borg, in Wild Strawberries, is at last able to reflect: "I was beginning to see a remarkable causality in this chain of unexpected, entangled events." (66) Perhaps in these day-end thoughts of Isak Borg, as well as throughout the art of Bergman and Bach alike, we have an echo of Goethe's meditation:

it is as if the eternal harmony were conversing within itself, as it may

have done in the bosom of God just

before the Creation of the world.

With music as both the subject and frequently the structure of the films, Bergman's cinematic work is eloquent testimony to the claim that, indeed, the strings of the lyre of modern poets are immense reels of celluloid. 


\section{Notes}

1. Rudolf Bultmann, Existence and Faith: Shorter Writings of Rudolf Bultmann, p. 26.

2. In Hans T. David and Arthur Mendel, The Bach Reader: A Life of Johann Sebastian Bach in Letters and Documents, p. 369.

3. Ingmar Bergman, The Magic Lantern, p. 281.

4. John Simon, Ingmar Bergman Directs, p. 16.

5. In Antonio de Nicolas, Powers of Imagining: Ignatius de Loyola, p. 24.

6. Cyrus Lawrence Day, The Songs of John Dryden, p. 76.

7. Oskar Sohngen, "Music and Theology: A Systematic Approach," in JAAR, Sacred Sound: Music in Religious Thought and Practice, p.5.

8. Leibniz, Opera omnia, Academy ed., VI, 484,438 (1671) (in Sohngen, p. 5).

9. Victor Zuckerkandl, Man the Musician, p. 7.

10. Juan Mascaro, The Upanishads, p. 113.

11. deNicolas, p. 24.

12. Lewis Rowell, Thinking About Music, p. 81.

13. Zuckerkandl, p. 7.

14. in Julius Portnoy, The Philosopher and Music, p. 56.

15. Birgitta Steene, Ingmar Bergman, p. 10.

16. Ingmar Bergman, Four Screenplays, p. 17.

17. Charles T. Samuels, "Ingmar Bergman: An Interview," in Stuart M. Kaminsky, Ingmar Bergman: Critical Essays, p. 102.

18. Ibid., p. 112.

19. Zuckerkandl, p. 83.

20. Ingmar Bergman, The Magic Lantern, p. 43.

21. Lise-Lorne and Frederick H. Marker, Ingmar Bergman: A Life in the Theater, pp. 30-31.

22. In Peter Cowie, Ingmar Bergman: A Critical Biography, p. 210.

23. Ingmar Bergman, Three Films, p. 126.

24. Robin Wood, Ingmar Bergman, p. 7.

25. The Oxford Companion to Music, p. 151.

26. Hans Theodore David, J.S. Bach's Musical Offering, p. 42.

27. Ibid., p. 43.

28. Douglas Hofstadter, Gödel, Escher, Bach, p. 10.

29. David, J.S. Bach's Musical Offering, p. 12.

30. Ruth Tatlow, Bach and the Riddle of the Number Alphabet, p. 20.

31. Gerardus van der Leeuw, Sacred and Profane Beauty, p. 260.

32. in Livingston, p. 248. 
33. Hans Theodore David and Arthur Mendel, The Bach Reader, p. 42.

34. Ingmar Bergman, Four Screenplays, p. 22.

35. Bjorkman, Stig, Torsten Manns, and Jonas Simas (eds), Bergman on Bergman, p. 212.

36. van der Leeuw, p. 238.

37. Birgitte Steene, Focus on The Seventh Seal, p. 67.

38. Cowie, p. 39.

39. Bergman on Bergman, p. 168.

40. cf. John Simon, Ingmar Bergman Directs, p. 143.

41. in Steene, Focus on The Seventh Seal, p. 51.

42. Wood, p. 72. 43. Ibid., p. 123. 44. Livingston, p. 243.

45. Charles T. Samuels, "Ingmar Bergman: An Interview," in Stuart M. Kaminsky (ed), p. 112.

46. Livingston, p. 243.

47. Ingmar Bergman, Images: My Life in Films, p. 86.

48. Ibid., p. 351.

49. Bergman, The Magic Lantern, p. 216.

50. Bergman, Images, p. 68.

51. Marker and Marker, p. 278.

52. Bergman, Images, p. 351.

53. Ibid., p. 359.

54. Karl Barth, Wolfgang Amadeus Mozart, p. 23.

55. Ingmar Bergman, Autumn Sonata, p. 51.

56. Livingston, p. 247.

57. Autumn Sonata, p. 28.

58. Ibid., p. 63. 59. Ibid., p. 18. 60. Ibid., p. 27.

61. Ernest Lubin, Chopin and His Circle, p. 92.

62. van der Leeuw, p. 222.

63. Kenneth B. Klaus, The Romantic Period in Music, p. 112.

64. Lubin, p. 92.

65. Steene, Ingmar Bergman, p. 23.

66. Four Screenplays, p. 279.

\section{References}

\section{Literature}

Barth, Karl. Wolfgang Amadeus Mozart. Grand Rapids, Michigan: Eerdman's, 1986 (1956) (foreword by John Updike; Clarence K. Pott, trans.).

Bergman, Ingmar. Four Screenplays. New York: Simon and Schuster, 1960. 
. Three Films. New York: Grove Press, 1970.

. Autumn Sonata. New York: Pantheon Books, 1978.

. Fanny and Alexander. New York: Pantheon, 1982.

. Images: My Life in Film. New York: Arcade Publishing, 1994.

. The Magic Lantern. London: Hamish Hamilton, 1988.

. Persona and Shame. New York: Grossman Publishers, 1972.

Bjorkman, Stig, Torsten Manns, and Jonas Simas (eds). Bergman on Bergman. New York: Simon and Schuster, 1973.

Boethius' The Consolation of Philosophy (Richard Green, ed). Indianapolis: Bobbs-Merrill Educational Publishing, 1980(1962).

Bultmann, Rudolf. Existence and Faith: Shorter Writings of Rudolf Bultmann. New York: Meridian Books, 1964.

Cowie, Peter. Ingmar Bergman: A Critical Biography. New York: Charles Scribner's Sons, 1982.

David, Hans Theodore and Mendel, Arthur. The Bach Reader: A Life of Johann Sebastian Bach in Letters and Documents. New York: W.W. Norton \& Company, 1966 (1945).

David, Hans Theodore. J.S. Bach's Musical Offering: History, Interpretation and Analysis. New York: Dover Publications, 1972 (1945).

David, Hans T., and Mendel, Arthur. The Bach Reader: A Life of Johann Sebastian Bach in Letters and Documents. New York: W.W. Norton \& Company, 1966 (1945).

Day, Cyrus, Lawrence. The Songs of John Dryden. Cambridge, Massachusetts: Harvard University Press, 1932.

de Nicolas, Antonio. Powers of Imagining: Ignatius de Loyola. Albany: State University of New York Press, 1986 .

Gado, Frank. The Passion of Ingmar Bergman. Durham, North Carolina: Duke University Press, 1986.

Hofstadter, Douglas R. Gödel, Escher, Bach: an Eternal Golden Braid. New York: Basic Books, 1979.

Jones, G. William. Talking With Ingmar Bergman. Dallas: Southern Methodist University, 1983.

Kaminsky, Stuart. Ingmar Bergman: Essays in Criticism. Oxford and New York: Oxford University Press, 1975.

Kawin, Bruce R. Mindscreen: Bergman, Godard, and First-Person Film. Princeton, New Jersey: Princeton University Press, 1978.

Kenneth B. Klaus, The Romantic Period in Music. Boston: Allyn and Bacon, Inc., 1970.

Livingston, Paisley. Ingmar Bergman and the Rituals of Art. Ithaca and London: Cornell University Press, 1982.

Lubin, Ernest. Chopin and His Circle New York: Amsco Music Publishing Company, 1975.

Marker, Lise-Lorne, and Marker, Frederick H. Ingmar Bergman: A Life in the Theater. Cambridge, UK: Cambridge Univ. Press, 1992.

Marshall, Robert L., "On Bach's Universality," in The Universal Bach: Lectures Celebrating the Tercentenary of Bach's Birthday. Philadelphia: The American Philosophical Society, 1985, pp. 50-81.

Mascaro, Juan. The Upanishads. New York: Penguin Books, 1983.

Milward, Peter. Landscape and Inscape: Vision and Inspiration in Hopkins's Poetry. Grand Rapids: William B. Eerdmans Publishing Company, 1975. 
Mosley, Philip. Ingmar Bergman: The Cinema as Mistress. London: Marion Boyars, 1981.

Otto, Rudolf. The Idea of the Holy. London: Oxford University Press, 1957 (1923).

Portnoy, Julius. The Philosopher and Music. New York: Da Capo Press, 1980.

Rowell, Lewis. Thinking About Music. Amherst: University of Massachusetts Press, 1983.

Simon, John. Ingmar Bergman Directs. New York: Harcourt Brace, 1972.

Sohngen, Oskar, "Music and Theology: A Systematic Approach," in JAAR, Sacred Sound: Music in Religious Thought and Practice, pp. 1-19.

Steene, Birgitte (ed). Focus on The Seventh Seal. Englewood Cliffs, New Jersey: Prentice-Hall, 1972.

Steene, Birgitte. Ingmar Bergman. New York: Twayne Publishers, 1968.

Tatlow, Ruth. Bach and the Riddle of the Number Alphabet. Cambridge: Cambridge University Press, 1991.

The Universal Bach: Lectures Celebrating the Tercentenary of Bach's Birthday. Philadelphia: American Philosophical Society, 1985.

van der Leeuw, Gerardus. Sacred and Profane Beauty. Nashville, Tennessee: Abingdon Press, 1963.

Wood, Robin. Ingmar Bergman. New York: Praeger, 1969.

Zuckerkandl, Victor. Man The Musician Princeton: Princeton University Press, 1973.

\section{Author Information}

Micheal BIRD (1941-2003) received his Ph.D. from the University of Iowa, and was Professor in Fine Arts and Religious Studies at the University of Waterloo, Ontario, Canada. A jazz pianist in spare time, he is author of ten books and many articles in the areas of film, art, religious studies, music and architecture. 